\title{
The Leader's Commitment In Bureaucracy Transformation At Regional Development Planning Board (Bappeda) Of Langkat Regency, North Sumatra Province In Order To Create Regional Development Planning
}

\author{
Beti Nasution*, Nurbani, Lina Sudarwati \\ Faculty of Social and Political Science, \\ University of Sumatera Utara \\ *betinasti@yahoo.com
}

\begin{abstract}
This study aimed to analyze: 1)the leader's commitmentin bureaucracy transformation at Regional Development Board (Bappeda)of Langkat regency. 2) The effectiveness of regional development planning formulated by Bappeda of Langkat Regency. This research used descriptive methods with qualitative and quantitative approaches. Primary data collection techniques were performed with indepth interview technique, observation and questionnaire. And secondary data collections were done by studying books, literature and related documents.The analytical methods that used are qualitative analysis by Miles and Huberman Model, and quantitative analysis using performance importance matrix. Research result; 1) Bappeda Langkat has transformed its bureaucracy but not optimal yet, caused by commitment of leaders is still weak in buraucracy transformation that can be observed from the organizational culture which is still not good, quality improvement of human resources as required, but not all employees can take part in education and training, and there is no evaluation of the implementation of education and training, incentives have not been executed transparently, not fair and not yet feasible. 2) Regional development planning has not been effective due; a) the funds were used for indirect expenditure greater than direct expenditures (development). b) Drafting process was not conducted in a holistic and integrated manner and not done in the deliberative. c) A pattern of decisionmaking in determining the program and budget has not involving the community in the overall development process.
\end{abstract}

Keywords: leader's commitment, bureaucracy transformation, the effectiveness of regional planning.

\section{INTRODUCTION}

The success of a country's development is highly dependent on the development planning formulated. Development planning is a function that is first and foremost in the development management and this is a foundation for the implementation of the next development management functions. To achive effectiveness of the regional area development planning, there are needed planning's intituion that have professional and responsible's habit.

Indonesian vast territory with a diverse community as well as the conditions of different regions, there may not be regional development planning is done centrally by Badan Perencanaan Pembangunan Nasional (Bappenas), then in the 1970s Badan Perencanaan Pembangunan Daerah (Bappeda) at the provincial level was formed and in the early 1980s the district level was established, because that, Indonesia has a development planning board from the central level to the region level.

Bappeda as the competent institutions that create policy (planning) is equipped with the organizational structure, duties and functions that obviously can not be delivered effective planning, so have not brought benefits for community's welfare in the regional in a fair and equitable. There is still a gap of 
development among regions, such

as between urban and rural. According to the BPS (2013), there are 28.55 million poor people that scattered in towns and villages with 0.413 of gini index, that showed the inequality is increased (Kompas Thursday, April 3, 2014).

Bappeda often gets criticism because it acts as a post office, which gives a stamp of approval for any proposed projects and programs, without assessing the suitability of these proposals with a vision of development that is outlined in the longterm plan of the region in order to fight for a coherent vision of development. Moreover, the Bapedda apparatus behaved indifferently.(Luc Spyckerelle and Farrazzi, 1997). Public bureaucracy in Indonesia in carrying out its duties seem slow, incompetent, not paying attention to the problems of society. Soebhan (in Wibawa ed, 2000) labels bureaucratic of Indonesian as "bureaumania" which is characterized by various forms of aberration such as the tendency of inefficiency, abuse of authority, collusion, corruption and nepotism. Whereas the main purpose of the establishment of the bureaucracy is that an organization can be run rationally, in order to achieve organizational goals effectively and efficiently (Zioni, 1985, Blau and Meyer, 1987).

Indonesia has been doing transformation of bureaucracy but has not shown any improvement in governance and development. According Rosyadi and Kurniasih (the Authority, ed, 2009) empirical facts show that reform of the bureaucracy is not going according to public expectations. Various practices of the public service still shows low quality and far from the aspirations of the public. The new reform only touch "the skin or surface", such as changes in nomenclature (Deputy Minister) but have not touched the substance. Bureaucratic reform based reward (remuneration) which is greater than the acceptance of bureaucratic elsewhere did not prove that better reward create higher productivity. As in Customs and the Supreme Court (Sedarmayanti, 2009).Dwiyanto (2008; 409) stated bureaucracy transformation in organizations of which the function that make policy done by improving the institutional side by reviewing the structure of the bureaucracy has been in accordance with the duties. If it is not clear it is necessary redefenisi tupoksi to fit with the vision and mission of the organization. After the improvement of bureaucratic structures need improvement such as the budget performance management, performance measurement, incentive systems, and other management tools.

Regional Development Planning Board (Bappeda) of Langkat has reformed the bureaucracy to renew the organizational structure in 2008. However Langkat regional development planning is not effective where the regional development program in Langkat outlined in RPJMD (2014-2019) not all be able to adopt people's problems because of the lack of fund/budget reason. This has implications that Langkat Regency still has a poverty rate of $11.3 \%$ (2015) and HDI of 68.53 is still below the average HDI of North Sumatra Province (69.51)

The efforts to change the most fundamental government bureaucracy is how to change minset and the behavior of the officers of the bureaucracy. The transformation of the bureaucracy in order to change the mindset and behavior to achieve effective performance is actually the leader of commitment. A leader must have the commitment to organize and direct all activities of the organization and also to be embedded in himself/herself to serve, have a sense of affection and attention on those they lead in order to provide a quality service to the community. China, Japan and South Korea succeeded in reforming the bureaucracy so that the results can be felt in accordance with the desired objectives because of the strong commitment of the leaders of each country (Eko Prasojo, 2008). Results of research Hamudy Ilham A. (2010) explains that the success of government reform in Jembrana influenced by heads of regions.

Based on the above research is conducted with the aim to analyze; 1) The commitment of leader in ransformation of the bureaucracy in Bappeda of Langkat Regency. 2) The effectiveness of regional development planning that is formulated by Bappeda of Langkat Regency. 


\section{MATERIALS AND METHODS.}

This study uses descriptive methods with qualitative and quantitative approaches. Primary data collection techniques were performed with in depth structured interviews with a tape recorder tools, observation and using questionnaires. Secondary data collections were done by studying books, related literature and documents. The analytical methods used are qualitative analysis by Miles \& Huberman Model and quantitative data were analyzed using performance importance matrix.

\section{RESULT AND DISCUSSION}

\section{The Leader's Commitment in Bureaucracy Transformation}

Bappeda of Langkat regency has done the renewal through changes in the structure of the bureaucracy, improving the quality of human resources and also incentives. The renewal of bureaucracy requires strong commitment and consistent leadership and high level of sensitivity to changes. The results of the questionnaire explained that the commitment of leaders of Bappeda of Langkat Regency based on several indicators such as; leaders desire to follow every activity together, the willingness to accept criticism from subordinates, the willingness to accept new ideas from subordinates, willingness to give confidence to subordinates, directives conformity with consistent behavior is all good. But the discovery of the field, the commitment of leaders in Bappeda Langkat in the transformation of the bureaucracy needs to be improved because it is still minimal. It can be seen from the dimensions;

\section{The Structure of Organization}

Organizational structure in Bappeda of Langkat was reformed in 2008 with a minimal pattern that consists of Chief of the Bappeda, Secretariat, Physical and Infrastructure Division, the Economy and Investment Division, and Research Division. The organizational structure in Bappeda Langkat has been in accordance with the basic tasks and functions of the Bappeda Langkat. The new structure is organised so that the rich functionality in a sense though minimal pattern are expected to adhere to the structure can carry out its functions especially in planning and development control area of Langkat. The duties and functions of any organizational structure has been implemented but could not provide effective results because the infrastructure is still lacking support. As for mapping territory (the making of maps and topographical photos) need a tool, but the tool that does not yet exist, so the work is less effective and the results obtained are less optimal. Some reveals that:

A. An important indicator in the execution of duties Bappeda is the ability to use the appropriate budgetary resources planning and overview of predetermined requirements as well as the capability and capacity of institutions to manage the service. Based on the respondents found that in the process of execution of the duties of each organizational unit Bappeda capable of using the budgetary resources according to the plan and an overview of the needs that have been arranged previously. The results also showed absorption of the budget or the use of the budget of each unit of work well (11\% very good answer and $78.60 \%$ answered either on the absorption of the budget in order of priority the achievement of objectives). This means that the use of the budget has also been in accordance with the requirements in the perception of the respondent. These conditions should give a description of the achievement of the activities and work programs are good also. However, in implementation turned out to the use of a larger budget for indirect costs (70-75\%) while for direct costs that only $30-25 \%$. ideally the most budget managed for the public welfare and communiy development. According to Dwiyanto (2008): "One that needs to be considered by Bappeda in managing the budget is planning to formulate accountability. Bappeda as bureaucratic institutions of government that has the main duties to make policy must make the interests and needs of the public as the main reference in the budget planning process and development. Bappeda should understand the needs of the community and stakeholders as well as making him the center of attention and the underlying value of the policy-making 
process and substance. For that Bappeda in making budget plans and regional development must be willing to involve communities and stakeholders, as well as responding to their aspirations. In this way, Bappeda will always be motivated to increase accountability".

B. Respondents explained that the structure has been given the ability and excellent willingness and if observed in a cross, the education level of employees in Bappeda Langkat that the majority of employees are college graduates. This is an overview of the capabilities and the ability Bappeda Langkat institutionally in managing services performed within their needs properly. But judging from the consistency of the implementation of the service found that in terms of the implementation of the institutional service Bappeda Langkat still a good consistency. This information is shown on the large number of respondents replied almost in a balanced answer for good and less good where there are $45.70 \%$ of respondents chose the answer is less good. In-depth research describes turns of the above related to performance evaluation. Performance evaluation not yet in the sense of a comprehensive and have not adapted to the main function of the Bappeda, create policy. Evaluation is only carried out at the administrative stage in the narrow sense that it just in the process of correspondence, working procedures and abide by the rules, but have not touched on the final result in comprehensive way.

C. Bappeda Langkat has had a key performance indicator of the presence of Spatial Planning, Plan for Special Economic Zones followed by the development plan that includes the Medium Term Development Plan and the Regional Development Plan. Spatial Planning regions in District Langkat has been made in accordance with the topography, but propriety in realizing key performance indicators is still unsatisfactory (57.4\% of respondents answered less well in the propriety realizing key performance indicators). This is because the spatial plan has not been followed in accordance with the development planning geography. Ideally, development planning is based on the concept of regional planning on the different spaces of different activities (different development) in accordance with topography (Rustiadi, 2010).

D. Changes in the structure of the bureaucracy has not been followed by a good organization culture. Bureaucratic structure that has been updated in accordance with the organization's needs not necessarily be implemented properly if it is not accompanied by good organizational culture. The success of the organizational structure not only on the clarity of duties and responsibilities and work flow of each section / field but also strongly supported the organization's culture better and stronger. Organizational culture are a number of important insights, like norms, values, attitudes, and beliefs, which is jointly owned member of the organization (Stoner, Freeman and Gilbert JR, 1996).

Glance at Bappeda Langkat's organizational culture has been pretty good, there is cooperation between fellow workers in one section (field), between employees interlocking between superiors and subordinates. But the reality shows in Bappeda Langkat's organizational culture still has the disadvantage of no less than pleasant working atmosphere as undervaluation management (direct supervisor) and low morale. This is due, first, the age factor between management and staff, which led younger age of its members, so members are less likely to appreciate the leadership. Second, a change in attitude, especially of employees who changed status from staff salaries to civil servants (PNS) which supporting employees (outsourcing) who have been appointed as public servants decreased morale in their duties. Thirdly, there is a non-job staff that transferred from other departments where staff were transferred suffered demotion (does not have a position) or non-job. The position of non - job impact on the behavior of the staff concerned the lack of discipline, morale is low, less concerned about the job. Another weakness in the organizational culture of Bappeda Langkat looks of values that apply in the application of labor discipline that only a morning rally discipline, promotions and transfers are not based on performance, incentives unfair, less worthy and not openly. 


\section{Human Resources (HR) Quality Improvement.}

Improving the quality of human resources for staff has been conducted and in accordance with the field of work, such as training for the staff of research division has benefited to the staff that they can apply the results of training on the job as making a research proposal. However the education and training of staff are not able to be followed by all of the staff because there are restrictions such as restrictions on the number of staff that can follow only one or two people, time to keep training and education are also limited to only 2 or 3 days.

However, Efforts to improve the quality of human resources for staff is still not shown good results. Based on the answers of the respondents found the ability of employees in critiquing and tendency to be transparent is still unfavorable (52.40\% answered less good). Likewise, disciplined awareness is still at 51\% answered less good. Work discipline is only measured on the timeliness attend morning assembly, yet refers to the process of the implementation of the actual work in order to correlate against performance. Whereas the health and physical fitness has been good (supported by $78.60 \%$ of respondents), as well as the indicator of religious obedience and worship showed that $83.30 \%$ responds well. However, physical health and spiritual level both on employees Bappeda Langkat not correlate with the ability to achieve the performance indicator. This is because there has been no evaluation of the results of education and training and behavior patterns minsdset governance still dominated by the old rigid and no longer compatible with the demands of the development to be carried Bappeda. Human Resource development efforts should ideally be evaluated whether already can improve their knowledge and skills. Knowledge and skills that will either encourage morale and lead to job satisfaction. However, the answers of respondents regarding the morale is still less good (52.90\% said morale is less good).

Education and training in order to update the knowledge and skills that are expected to renew the work behavior should not be limited in number. All employees have the opportunity to develop quality in accordance with the needs and work field respectively. Leaders have the authority to determine effective education and training for employees, with the education and training plan, design and evaluate, not dependent on external demand. In accordance with the opinion of Mathis and Jackson (2006; 309) strategic training can be implemented effectively through a four-stage process, namely: 1 . assessment, 2 . design, 3 . delivery, 4. evaluation of training.

Training needs analysis and the development of an assessment of knowledge and skills employees need today and in the future. Then based on performance appraisal is known who is in need of education and training and training/ education what is required of employees. Once established training and development needs and who need training and development then training and development activities designed. Implementation of educational activities associated with the design and then there is an evaluation. The success of education and training is not only seen on the output (number of staff have the education or training) but also its outcome, namely changes in knowledge, skills and changes in attitudes and behaviors in the work. The next leader must reward pegawaai who have been successful education and training in order to motivate employees to perform better. Mulyana Research (2005; 42) describes the necessary commitment of leaders for immediate repair of the factors that power work motivation (external motivation).

\section{Incentive Systems}

The incentive system is any form of remuneration and also an extra motivation for achievement that exceed the standards that have been set and approved together. Incentives as motivation can be provided in the form of money and promotion were given as a reward for performance that exceeds the standards. Incentives thus made after an objective performance assessment. 
Incentives in Bappeda Langkat follow the rules of the system of incentives that apply nationally. Incentives in the workplace Bappeda Langkat is not different from other work units in other areas. However as the autonomous region, granting incentives adapted to the abilities of each region. Incentives on direct salary given is based on consideration of class/grade and position (echelon). Incentives in the form of salary is not based on performance appraisal of each staff, so that all staff have the same grade earn the same salary great though the performance is different. Besides the fixed salary there is incentive that given for supplement called Improvements Income Allowance, which amount is given based positions structural and also based on the amount of attendance to follow morning assembly, if the staff do not meet the schedule for morning assembly in accordance with the provisions of the incentive will be cut.

Results of respondents descriptively explained that the embodiment incentives for employees in the Office of the Bappeda Langkat still less good. This is demonstrated by several indicators, among others; suitability indicators of granting incentives with the needs of the job is still less good (55.20\% answered less good). Indicator of fairness in the realization of the incentive is considered less good ( $50 \%$ answered less good), as well as the feasibility of providing incentives is still not worth (54.80\% answered less worthy) and information transparency in the granting of incentives is also considered unfavorable (55.2\% answered less good). Incentives do not always involve a nominal amount of money gained by the employee but also must be applied equally to all employees so as to create a conducive working environment. Implementation of incentives also requires clear disclosure of information among employees of Bappeda Langkat.

Providing incentives to improve employee motivation at Bappeda langkat also does not vary and is not associated with the needs of employees. Incentives as remuneration for the provision of performance and also rewards (promotion) in order to increase motivation to work should be done in a varied and associated the person receiving the incentives. Such as the desire of the research part able to get the order they were sent for education to the S2 level. Promotion staff as a tribute is still less objective. Promotion as the award is not based on rating performance, but more priority to employee loyalty and because there is a "factor x". Loyalty is also not clearly defined. As the above findings that the evaluation of the performance is still limited to an evaluation of procedures and correspondence in the strict sense, there has been no clear assessment of performance and measurable results that must be done first in Bappeda langkat. Providing incentives for fair, equitable and open to be correlated with a good work culture. According Dwiyanto (2008);

Eko Prasojo also stressed that " the leader's role is huge in bureaucratic change. Bureaucracy will not be possible to make changes to itself without the support of the political commitment of leaders, be it of Ministers, Secretary General, Governor, Regent / Mayor. Because the bureaucracy does not have the authority of a political nature. But once get that authority, then the bureaucracy in Indonesia is patron clien relationship will make those changes. "If a good leader, usually the bureaucracy will come good. (Eko Prasojo 2013). Thoha (2009) expressed a need for change and renewal of the state apparatus it depends on the need for a renewal of national leadership. If the national leadership felt the need to make changes definitely change and renewal apparatus will be realized. It needs to be supported by a strategic policy and made a national program with the support of all components of the people, then change and renewal apparatus of state/ government can do.

\section{EFFECTIVENESS OF REGIONAL PLANNING}

Effectiveness of regional planning visits of suitability development programs with issues/ problems facing the community process of its formulation is based in deleberatif, by involving the community in the overall development process ranging from problem identification, development programming, budgeting and evaluation and design development programs utilizing the potential of the area both potential human and natural resources and social resources as well as planned in a holistic and integrated. 
Based on the documents RPJMD (20142019) in Chapter IV, various problems faced by the community has been accommodated. RPJMD (2014-2019) includes among other issues; problems of infrastructure and spatial planning, land use change, the problems of the economy, employment, SMEs and cooperatives, investment, food quality, agriculture, commerce, industry and cultural tourism, issues of poverty, issues of education, health issues, and environmental problems. With all the problems of society are expected to cover programs/ development activities proposed in the Development Plan actually related to the problems and needs of the community so as to supply of community life.

Due to limited funds programming shows that just relying on the availability of budget. Budget constraints can actually be overcome by utilizing social capital, namely the existence of consensus and the spirit of mutual cooperation which is the local people's habits. Consensus and mutual assistance has been used since time immemorial community to address the issues facing society, and this is a development capital (social capital). Social capital has been shown to play a role in development and that the government should issue a policy to strengthen and develop social capital in order to participate in the development. Sumarto argued (2003) that social capital is the foundation for building a strong civil society and is believed to affect the progress of the economy and the distribution of profits. Research by (2015) also explains that social capital (consensus and mutual assistance) can be used to overcome the problems of farmers in Serdang Bedagai impact on increasing agricultural yields (outputs) and impact on increasing farmers' income. However, based on documents RPJMD langkat (2014-2019) and RKPD (2015) there has been no policy of strengthening or development of social capital.

Regional development planning in Langkat less effective than caused due to ineffective use of the budget is also due to the drafting process was not done in a holistic and integrated and not deleberatif and patterns of decision-making in determining the program has not been fully involve the community. The development program as a policy to address various issues in society should be undertaken in a holistic and integrated namely the existence of inter-sectoral coordination and linkages with other sectors see that the development program planned to overcome the various problems are interrelated. Therefore in identifying community problems should be viewed association with other problems that may be related. However, in the implementation process of programming through Musrenbang at the village, sub-district and district level conducted separately were divided into three groups, namely the Field of Physical, Economic Development and Social Culture. Musrenbang with the distribution of these groups certainly can not integrate issues are interrelated, each sector of the view that the program should be prioritized. Here we can see their ego in the preparation of sectoral development plans that result in less effective planning.

Though Musrenbang District involves various elements of society such as; BPD (Village assembly), LPMD (Village Community Empowerment Institution), Youth, PKK (Family Welfare Program), village leaders, traditional leaders, religious leaders and youth leaders. But a final decision in determining the program and budget setting is in the leadership of Bappeda and also on education. Community involvement in the preparation of programs / activities and budgeting for development is certainly only raised the question and participate in diskuisi forum to discuss development programs. The final decision is in the government. Community participation in the development process in Langkat yet fully in the start of a process to identify problems, develop the development program, preparing the development budget, the implementation of development and conducting evaluations. These types of participation by Moyinihan (2003) is a type of partial participation level of representation widespread, involving different interest groups but provided opportunities for participation in the session is limited. This suggests that the process of development planning in the region of decentralization has not been implemented according to the principles of decentralization which is planning to do with community participation in the entire development process from planning, implementation and evaluation.

It is indicating the that the transformation of the bureaucracy, especially in the institution in 
charge of giving birth public policies should 2 involve full public participation. According to Ilham A. Hamudy governance reform in the region is also influenced by the degree of public participation in the formulation of government policy. This is supported by research conducted Sumarto $(2009 ; 22)$ which shows that in Kebumen Regency, Bandung, Sumedang Regency, Surakarta, and the town of Pare-Pare, in addition to support for regional heads, governance reform in the region are also affected public participation, political support legislature, bureaucracy, civil society and include academics / ekspertise (in Ilham A.Hamudy, 2010). Furthermore Sedarmayanti asserts that "the commitment of leaders in the organization that gave birth to the policy should ideally use the" paradigm of public policy "or" public deterministic paradigm ". Said the public is not only used in the sense of "government", but also the state and society, including interest; responsibility, and engage the general public in the whole process of public policy and the country. The paradigm of public policy will bear public policy that is responsive to the principles; participatory, democratic and openness as attitudes and behaviors to accept new ideas, listen and act on criticism and response to community issues, reward innovation and creativity.

\section{CONCLUSION}

1) The commitment Bappeda of Langkat leader in the transformation of the bureaucracy in Bappeda langkat is still low/less, it still needs to be strengthened further. It can be seen from the structure of the organization, although the functions of each of the organizational structure has been implemented but not yet able to provide effective results that can be seen from have not been consistent in the implementation of the service. Still less pleasant working environment such as lack of respect for the leadership (direct supervisor). The increasing of Human Resources qualityhas also been made, but still did not give optimal results. The incentive system has also been implemented but information on the incentive system is not open, yet performancebased and not implemented in a fair and reasonable and not based on the risk of the job.
The planning for regional development is less effective because not all of the problems faced by the community responded by development programs and there are less funds priority scale, the process is not done deliberative preparation and decision making patterns in determining the program and the budget has not been fully involve the community in the whole process development and not done in a holistic and integrated.

\section{REFERENCES}

Blau, Meyer. (1987). Bureaucracy in Modern Society, second edition, Jakarta, UI Press

Bryant, Coralie and White, Louise. (1989). the Management Development for Developing Countries, LP3ES, Jakarta ,.

Chambers, R. (1974). Managing Rural Development, New York: Holmes and Meier

Dwiyanto, Agus. (2008). Achieve Good Governance Through Public Service, Yogyakarta, Gajah Mada University Press.

Dwiyanto, Agus, et al. (2003). the Governance Reform and Regional Autonomy, the Centre for Policy studies Kep haendudukan and Gajah Mada University, Yogyakarta.

Etzioni, Amitai. (1985). Modern Organizations, Jakarta, UI Press.

Glasson, John. (1997). Introduction to Regional Planning, translated Sitohang, Faculty of Economics, University of Indonesia, Jakarta.

Hersey, Paul, Ken Blanchard. (1992). translator Agus Dharma, Management of Organizational Behavior, Human Resources, Publisher, Erland.

Korten, David, C. And Syahrir, (Editor). (1998). Development PopulistDimensions, Obor Indonesia.

Mhatis, L Robert and Jackson, John. (2006). Human Resource Management, translators, Diana Angelica, 10th edition, Salemba Four, Jakarta.

Osborne and Gebler. (1995). Entrepreneurship Bureaucracy, Reinverting Government, 
translator Abdul Rosyid, PT Teruna Graphic, Jakarta.

Osborne and Plastrik. (2004). Trimming Bureaucracy Five Strategies Towards Entrepreneurial Government, Jakarta: PPM

Sedarmayanti. (2009). the Public Administration Reform, Reforms, and Future of Leadership, (Delivering Service Excellence And good governance), Bandung,

Revika Aditama. Soegijoko, Budhy Tjahjati S, editors. (1997). Anthology of Development Planning in Indonesia, PT Gramedia Widiasarana Indonesia, Jakarta.

Sumarto, Hetijah Sj. (2003). Innovation, Participation and Good Governance, Obor Indonesia

Thoha, Miftah. (2003). Bureaucracy and Politics in Indonesia. Jakarta, Raja Grafindo Persada (2002). Behavioral Perspective Bureaucracy, dimension-Dimensional Prima State Administration of Science, vol II, Jakarta, King Grafindo Persada

- (2009). Reforms, the Authority, Samodra 2009, the State Administration, Contemporary Issues, Graha Science.

Wibawa, Samudera. (2009). Public Administration, Contemporary Issues, Yogyakarta, Graha Science.

Alfatih, Andi. (July 2004). Empowerment for Administrative Reform Through Administration, State Administration Journal, Volume 4 NO 2,.

Hasibuan, Sayuti. (July 2004). Vision, integration, competitiveness, and Institutional Transformation, Development Planning, Quarterly Magazine, Medical Information, Professions, Communication Planning and Development, No.07 / 1997, January.

Spyckerelle, Luc; Ferrazzi. Gabrielle. (1996). Development Planning At the level of the district, Prisma, magazine Economic and Social studies.

Muluk, Khairul, Construction Failures, Lessons for Planning, Regional Development, Public Spirit, Journal of Administrative Sciences, ISSN, 1907-0489, vol3 NO.1 2007.

Martilla, John A. And James, John C., 1977, "Importance-Performance Analysis" Journal of Marketing, p77-79, ABO / INFORM Global.

Mulyana. (2005). Motivation Development Strategy to Improve the Performance, Journal of Local Government Administration, ISSN, 1829-5190, vol Ii, edition, sixth

Journal of Human Resources. (October 2016). Blogspot.com.id/2009/07/teori leadership Maxwell, (Accessed 5 October 2016).

Yakobtomatala.com 2010/02/28 / how important leadership commitment, (accessed 5 October 2016) 